\section{UNHIDING THE HIDDEN PORTRAIT OF PAHLAVI WOMEN BUILDERS IN SKETCHING THE IRANIAN MODERNITY: A REASSESSMENT OF THE CONGRESS OF WOMEN ARCHITECTS (1)}

\author{
Baharak TABIBI*
}

Received: 06.06.2020; Final Text: 01.03.2021

Keywords: Women architects; female patronage; Iranian architecture; Pahlavi modernity; Shahbanu Farah Pahlavi

1. This paper is based on the author's PhD dissertation; "Propagating "Modernities": Art and Architectural Patronage of Shahbanu Farah Pahlavi" submitted in 2014 to METU Architectural History Graduate Program under the supervision of Prof. Dr. Belgin Turan Özkaya.

2. The author defined the Iranian form modernity as a "hybrid" one; that was shaped in recurring theme of duality manifested on different levels between contemporary and traditional, universal and local, and imported and native.

\footnotetext{
* Department of Architecture, Faculty of Art, Design and Architecture, Istanbul Okan University, Istanbul, TURKEY.
}

\section{INTRODUCTION}

During the eight decades of the Pahlavi monarchy, a particular conception of modernity (2) had been generated through several constructs of westernization, centralization and nationalism. The dynamic process through which Iran's determination of modernity was formed represents an intriguing blend of these concepts within a wider socio-cultural relationship that penetrated the key aspects of the country's modernization project. The Pahlavis' revolutionary program (3), indeed, was not only effective in the political sphere, but also in the broader cultural circumstances of modern Iran. In much of the $20^{\text {th }}$ century, an imposed and a pre-defined cultural program (4) dominated the ideological perspective of the Pahlavi state to appropriate their modernist ideology from above. The operation of high-culture in politics was accordingly conceived by royal hands and in particular by the shahbanu of Iran whose significance was exemplified by the very symbolic part she took in the 1967 coronation ceremonies where she was entitled as the first queen-regent in the Iranian history.

The ideology of forming modern Iran under the leadership of the Pahlavi monarchs directed the state policy toward a series of reforms in which the question of women was seen as central in legitimating the state's larger political agenda of modernization. The leaders' apparent contributions to the expansion of women's rights (5) were to terminate, albeit superficially, the segregation of women in society. And the prerequisite for the modern emancipated woman was seen as gender representation and women's integration in various social, political, cultural and educational fields. An official feminism indeed was to be promoted from above to appropriate the ideology of the modern state for the modern Iranian woman.

In proselytizing the state's policies on gender issues and women's emancipation, female members of the royal family had unique qualifications. For the Pahlavis, the shahbanu, like her predecessors, was 
3. Also called as White Revolution, this was a development plan culminating in nineteen-point reform program including Land Reforms, Nationalization of Forests and Pasturelands, Privatization of the Government Owned Enterprises, Profit Sharing for Industrial Workers, Female Suffrage Law and Extending the Right to Vote to Women, Formation of the Literacy Corps, Formation of the Health Corps, Formation of the Reconstruction and Development Corps, Formation of the Houses of Equity, Nationalization of Water Resources, Urban and Rural Modernization and Reconstruction, Didactic Reforms, Modernization-Decentralization, Employee and Public Ownership Extension Scheme in the Industrial Complexes, Price Stabilization, Free and Compulsory Education, Free Nutrition for Needy Mothers, Introduction of Social Security and National Insurance, Stable and Reasonable Cost of Renting or Buying of Residential properties and Introduction of Measures to Fight Corruption.

4. In 1975, the shah decreed a one-party system to complete his revolutionary missions by taking over the main state organizations including the Ministry of Arts and Culture. Power was to be exercised by a group of selected upper echelon of Iranian society while above them the state was influential in shaping Iran's mainstream high-art and cultural agenda.

5. Initiated in 1968, the secularization of women's emancipation was a part of Mohammad Reza Shah's modernization program attempting to bestow social, cultural and political empowerment to modern Iranian women. In a similar manner, gender equality had been a part of a larger political agenda of modernity and an inescapable part of Reza Shah's reformist program; granting women's accession in modern professions concerning education and workforce participation.

6. For more detail on Farah Pahlavi's contribution in the fields of arts and architecture refer to the author's unpublished PhD dissertation: Propagating "Modernities: Art and Architectural Patronage of Shahbanu Farah Pahlavi. seen as an ideal archetype of emancipated Iranian woman and the de facto ruler in shaping the state's comprehensive modernization policies agenda in cultural fields. Handed the reign, as a former architectural student, the shahbanu exploited the manifest power of culture as agency in the workings of the Iranian politics (6). Her advocacy for modernization was to be materialized through constructing and renovating buildings, establishing art centers, institutionalizing museums, and organizing symposiums and conferences on art and architecture since culture was an appropriate instrument to legitimize politics.

In their latest ride towards modernization, under the royal patronage of the shahbanu, the idea for organizing the Congress of Women Architects was emerged in 1976. With the participation of a well-known female architects group, the event aimed to propagate the Pahlavis' gender libration ideology via subscribing an inclusive-femininity versus the hegemonic masculinity in the definition of Iranian modernity. The congress was not only a platform for women architects to be identified as active agents in reconstructing Iran as a modern country, but also it was an attempt in rethinking gender instrumental role in shaping and directing the narration of modern Iranian architectural history and historiography.

\section{A GENDER GAP: NEGOTIATING WOMAN, ARCHITECTURE AND HER_STORY}

"I was fairly depressed by the atmosphere... There were only five or six girls in our studio [at the Ecole Speciale d'Architecture] Most of the boys made fun of us and put us down. There's never been a girl who's become an architect worthy of the name" (Pahlavi, 2004).

The establishment of the first architectural school in Iran dates back to 1927. Founded in Daralfonoun by the Iranian architect Karim Taherzadeh Behzad, it was the first higher educational institution in the Western sense to provide training for male students. Within a decade, the institution was re-established as the School of Arts and Crafts in the Fine Art School of Tehran and transferred to the Higher School of Arts in 1938. The newly established School of Fine Arts and Architecture was accepted as the first Iranian school of contemporary architectural education at Tehran University under the tutelage of the French archeologist and architect Andre Godard and the Iranian Beaux Arts educated architects, Mohsen Foroughi and Houshang Seyhoun as the first two directors. Until its administration changed hands in the early 1960s, the school trained an entire generation of Franco Iranian architects in the classic pedagogic Beaux-Arts programs as transferred to the Iranian setting. Although the architecture curriculum attracted a significant number of students during the first five years period of its establishment, the number of practicing architects was no more than thirty five in 1944 (Khajouy, 1946), no women among them.

In practice, it took a short period after the establishment of the first architectural institution in Iran for women to be accepted in the profession. In 1943, three years after the establishment of the School of Fine Arts and Architecture, the first woman gained entrance to the department; and in 1945, Nectar Papazian Andref became the first Iranian woman with graduate diploma in architecture. During the following two decades, women were still not numerous in the profession. In 1967, while the number of registered architects with the Iranian Society of Architects increased to a hundred and twenty one, only eight of these practicing 
members were women. Among them were Nectar Papazian Andref, Victoria Ohanjanian-Fard, Leila Farhad Motamed, Guiti Afrouz Kardan, Moloud Nejat, Roza Mirzaian, Aghdas Vafa and Azar Safi-Pour (Iranian Society of Architects, 1976).

There are limited sources of information about this first generation of women architects; either they are known by names or they are linked to buildings, but their involvement remains uncertain. In addition to the Report of the Proceedings of the Congress of Women Architects, an issue of Journal of Art and Architecture devoted to female architects and published during the events of the congress enables us to identify these figures among some others whose works and contributions to the development of modern Iranian architecture during the Pahlavi period can be documented.

A general overview on the field of professional practice by female architects during the last decade of the Pahlavi period demonstrated that, although the bulk of construction activity of the time was undertaken by the private sector, women architects were widely participating in public institutions and state planning organizations such as municipalities, the Plan and Budget Organization, the Ministry of Housing and Urban Planning and the High Council of Urban Development and Architecture. The second half of the Pahlavis' era, with the U.S. Marshall Plan and Point Four Programs, witnessed a series of National Development Plans. New urban settlements were accordingly begun and existing urban centers upgraded. New master plans and large-scale public building programs became a basis of public policy (Ardalan, 1986). Foreign educated architects and newly trained practitioners in Iran were jointly commissioned in developing designs for several major projects. By the same token, women architects put their direct impact on national planning and local construction capability, among them Mahvash Nezami set up practice as one of the first women architects to be involved as the supervisor of Tehran's Detailed Plan at the Tehran Municipality in 1970. By 1976, Nezami had been the Director of Master Plans and the Deputy of the Urban Development Plans Office in the Ministry of Housing and Urban Planning. Similarly, Soraya Birashk was the Director of the Plan and Budget Organization and worked in charge of Master and Detailed Plans in Urban Development and Housing Management in 1973. The studies and preparation of Master Plans for old and new towns in Khuzestan, Bushehr, Kerman, Zahedan and Mazandaran regions were completed by Azar Faridi. A further important figure was Nahid Denbali who worked at Housing Organization and Isfahan Municipality (Mansouri, 2007).

The establishment of strategic priorities and Master Plan for Tabriz was the work of the first Iranian woman architect, Andref. Team-Working was not an obstacle to Iranian women architects making their contributions at private firms while directing the state's planning operations. Working as head of an architectural office, Andref was the first female architect carried out her professional work with male collaborators for various educational buildings (7). In the same vein, Nasrin Faghih built her solo career through working in partnership with a male colleague in their firm for many educational, cultural and residential complexes as project manager while involving in the projects of the Ministry of Housing and Urban Planning for the Isfahan Master Plan (8). Similarly, Leila Farhad Motamed's jointwork with her husband won her attribution to many residential and educational projects. gained PhD from Beaux Arts in 1956 Andref's most influential contributions were Master Plan for Tabriz, Master Plans for Pahlavi and Jondi shapour Universities and some related faculties, Farah Pahlavi Customs Buildings, Red Lion and Sun Society Hospital.

8. Graduated from Istituto Universitario di Architettura with a PhD degree in 1969, Faghih attended Yale School of Architecture for a master degree in Environmental Design in 1974. Faghih's most important works were Master and Detailed Plans for Isfahan and Aryamehr University. 
9. A graduate of the Universita di Roma with a PhD, Hessamian's most influential involvement was National Iranian Petrol Office.

10. A graduate of the Universita di Roma in 1960, Azemoun participated in Tehran University Hospital and Ramsar Airport projects.

11. Trained at Michigan State University, Radpour started her career at Pahlavi University where she was involved in the university's technical office projects.

12. Educated in Austria, Seraj worked for Tehran Municipality.

13. Participated in Master Plans for Rasht and Astara, Samie worked in the High Council of Urban Development and Architecture.

14. Educated at Tehran University and later at UCLA, Ehsan continued her academic career at Rensselear Polytechnic Institute where she was charged with the university's campus plan. In 1970, as a professor at Harvard, she participated in many residential, commercial, and institutional projects; among them was Commercial and Ocean Front Recreational project in Los Angeles.

15. The congress was the third international event on architecture, part of a series envisaged to be held every four years after 1970. 'The Interaction of Tradition and Technology' was the main theme of the first meeting of these series with the participation of the world leading architects and urbanists in Isfahan; followed by three annual symposia on the problems of agriculture, urban development and environmental planning on the national platform. Three years later in 1974, the second Iranian International Congress of Architecture and Urban Planning was presided over by the shahbanu under the principal subject of 'The Role of Architecture and Urban Planning in Industrializing Countries' with the participation of practicing distinguished Iranian and foreign architects in Shiraz, Persepolis.
It was not only Western-educated women architects, but also foreign women practitioners who were extensively involved in many architectural projects in their private firms in Iran. As much is known about these figures as about the Iranian women architects. Their mostly joint work with their male partners enables this research to identify some of these architects and their contributions (Women Architects, 1976, 47-61); among them were Moira Moser Khalili, Franca de Gregorio Hessamian (9) and Rosamaria Grifone Azemoun (10).

During 1970s, a number of female-owned architectural firms were emerged gradually among them Banu Consulting Architect was the first small self-employed female-owned firm formed by Keyhandokht Radpour (11), Shahrzad Seraj (12) and Mina Samie (13) in 1974. Mainly involved in administrative projects, the firm also took on various social and cultural buildings (Women Architects, 1976, 75-81). Another female directed architectural office formed by Noushin Ehsan in 1975 who worked as a chief designer in planning of various commercial, institutional, educational and medical buildings during 1970s both inside and outside the country (14).

While limited archival information about women practitioners has restrained a comprehensive study of women architects, it provides a general overview on the educational background and public status of women in the architectural profession of Pahlavi Iran. The reports and written documents devoted to female architects demonstrated that during the last two decades of the Pahlavi monarchy, women architects had been recognized widely for their important individual contributions in private architectural offices, public institutions, governmental organizations, and educational establishments.

\section{PUSHING THE BOUNDARIES: A CONGRESS FOR WOMEN ARCHITECTS}

"Were I not what I am today, I would wish to be an architect, that is really where women should have much to say" (Pahlavi, 1978).

In 1976, under the patronage of Shahbanu Farah, the first international congress dedicated to women architects in Iran was organized in Ramsar (Figure 1). The congress was the third international event on architecture, part of a series envisaged to be held every four years under supervision of the institution of monarchy in materializing their cultural revolutionary program (15).

The idea for an international event on female architects had originated in a meeting of Shahbanu Farah and Madame Solange d'Herbez de la Tour, the founder of the International Union of Women Architect in Paris one year earlier in 1975 (Shaghaghi, 1976c). Established in 1963, the U.I.F.A was the first foundation with the aim to "settle up the history of women architects" in national and international levels via meetings, organizations and congresses (U.I.F.A., 2009). First organized in Paris and followed by a congress in Monaco and then in Bucharest, the fourth international organization devoted to female architects encompassed the regions of the Middle East and was organized in Iran with the 'Development Of An Architecture of Pacification Rather Than Aggression' as the main theme of the congress (U.I.F.A., 2001). 

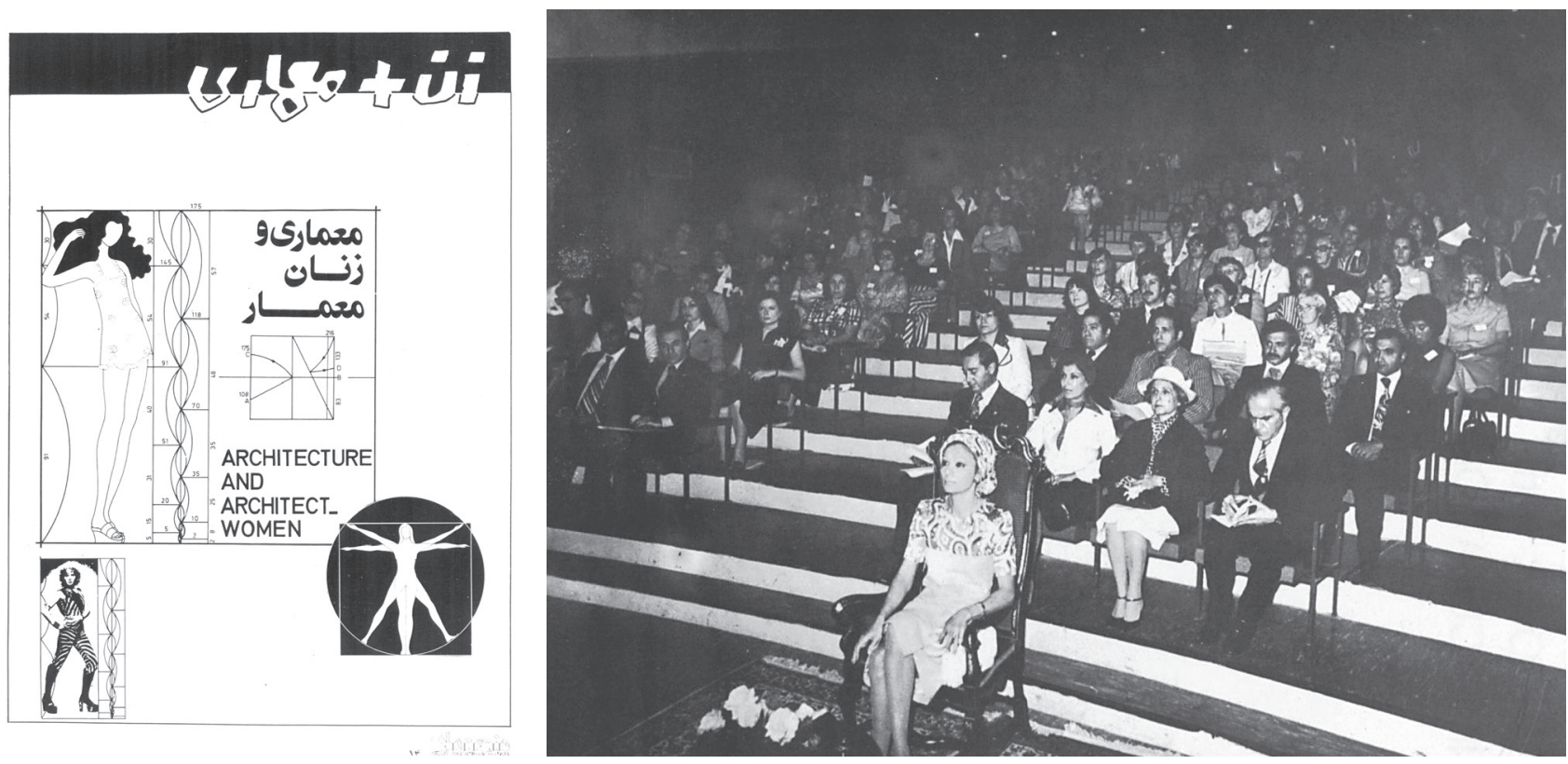

Figure 1. The Poster of the Congress of Women Architects propagated in the Journal of Art and Architecture (Journal of Art and Architecture, 1976)

Figure 2. Shahbanu Farah Pahlavi in the inaugural speech of the Congress of Women Architects (The Crisis of Identity, 1976)
Figure 3. The shahbanu visiting women architects' architectural exhibition (The Crisis of Identity, 1976)

Figure 4. Female architects in the inaugural speech of Congress of Women Architects (The Crisis of Identity, 1976)
A number of Iranian women architects, subsequently, were invited to attend a meeting at the Ministry of Housing and Urban Development. From them Azar Faridi, Noushin Ehsan, Guiti Kardan, Leila Afkhami, Nasrin Faghih and Shahla Malek were elected as the executive committee to establish the framework to conduct the event (Ehsan, 1976). Opened on 13 October, the formal congress was planned as a four-day session, with three-day of lectures (Figure 5), seminars, discussions and meetings (Figure 6) revolved around three subthemes of Identity, the Crisis and 'he Role of Women in the Crisis and Search for Identity and a final day for resolutions to be revised by the participants (Figure 7).

The theme was tackled by a group of foreign attendees from twenty-three countries around the world (Figure 4). Guest included Indira Rai and Eulie Chowdhury from India; Alison Smithson, Monica Pidgeon, and Jane Drew from England; Denise Scott Brown, Joyce Whitley, Ellen Perry Berkeley and Ann Tyng from U.S.A.; Nobuko Nakahara from Japan; Marie Christine Gangneux and Delatur from France; Anna Bofill from Spain; Gae
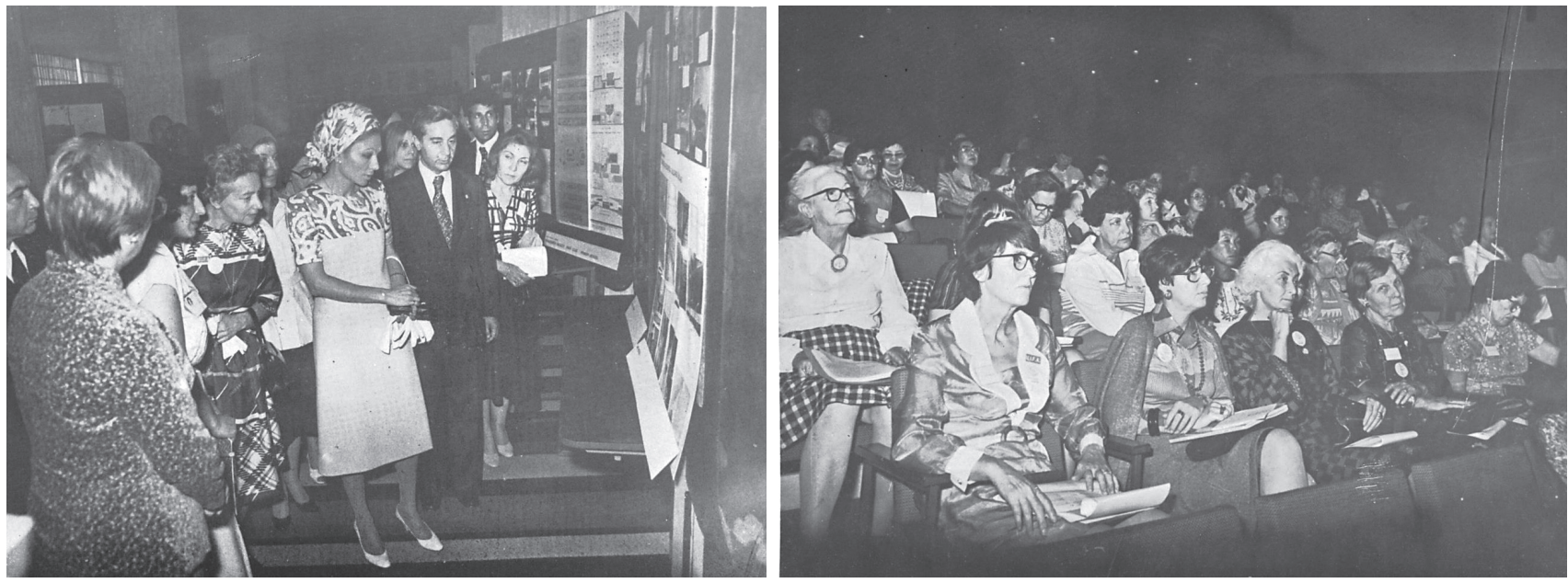

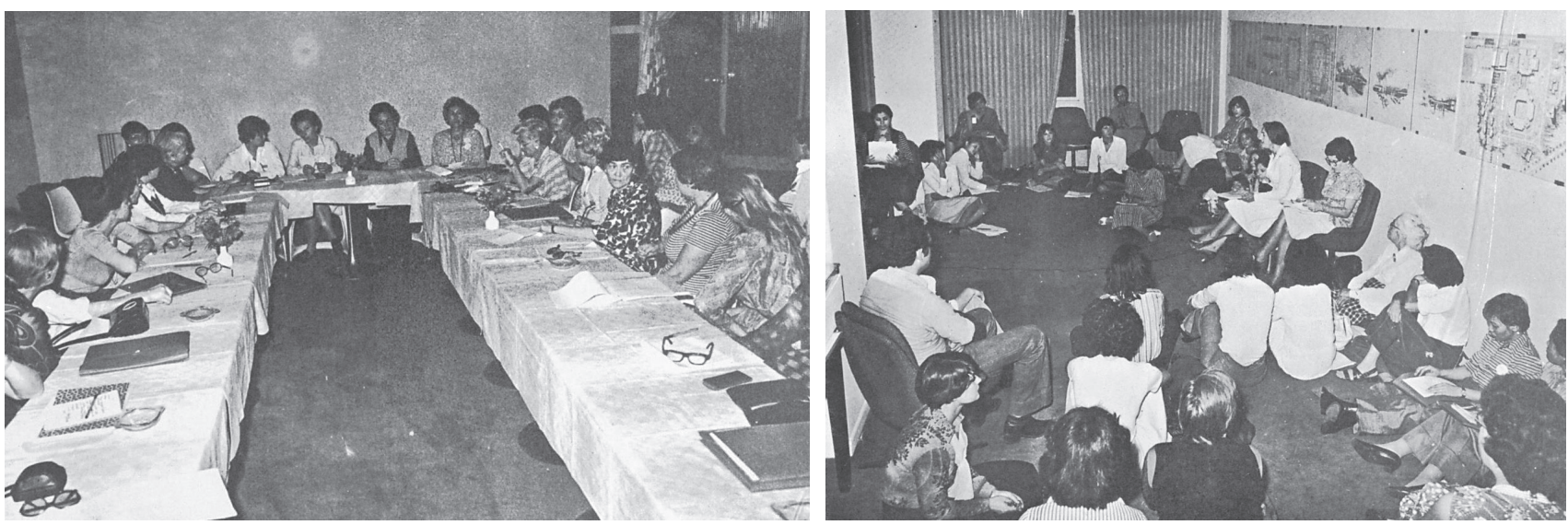

Figure 5. Women architects in a lecture in the Congress of Women Architects (The Crisis of Identity, 1976)

Figure 6. Women architects' meeting in the Congress of Women Architects (The Crisis of Identity, 1976)

Figure 7. Discussing a series of resolutions after the Congress of Women Architects (The Crisis of Identity, 1976)

Figure 8. The Congress of Women Architects (The Crisis of Identity, 1976)
Aulenti from Italy; Bola Sohande from Nigeria; Mona Mokhtar from Egypt; Hande Suher from Turkey; Nelly Garcia from Mexico; Hanne Kjerholm from Denmark; Laura Mertsi from Finland; and Helena Polivkova from Czechoslovakia (Women Architects, 1976, 17). In addition an articulated group of Iranian architects attended including Rosa Maria Grifone Azemoun, Laleh Bakhtiar, Noushin Ehsan, Francade Gregoria Hesamian, Moria Moser Khalili, Keyhandokht Radpour, Shahrzad Seraj, Mina Sameie, Leila Sardar Afkhami, Guiti Afrouz Kardan, Nasrin Faghih, Zohreh Chargoslo, Mina Marefat, Yekta Chahrouzi, Silvana Manco Kowsar, Anne Griswold Tyng and Laila Farhad Motamed (Figure 3).

In the inaugural meeting, the shahbanu denoted the aim of convention as to interchange ideas among the representatives of various cultures and emphasized the role of women architects as the symbol of modernity in the cultural advancement of the country. More emphasized that, the project of an assembly of female architects was not an attempt to conceptualize femininity and feminine representation within the architectural profession of modern Iran, nor was it to question gender dynamics and the social policies of the Pahlavis (Figure 2). In the same manner, the role of female practitioners in the dynamic process of the Pahlavi's revolutionary reforms was the main subject of the Minister of Housing and Urban Development opening speech; followed by Andref's introductory remarks in which she
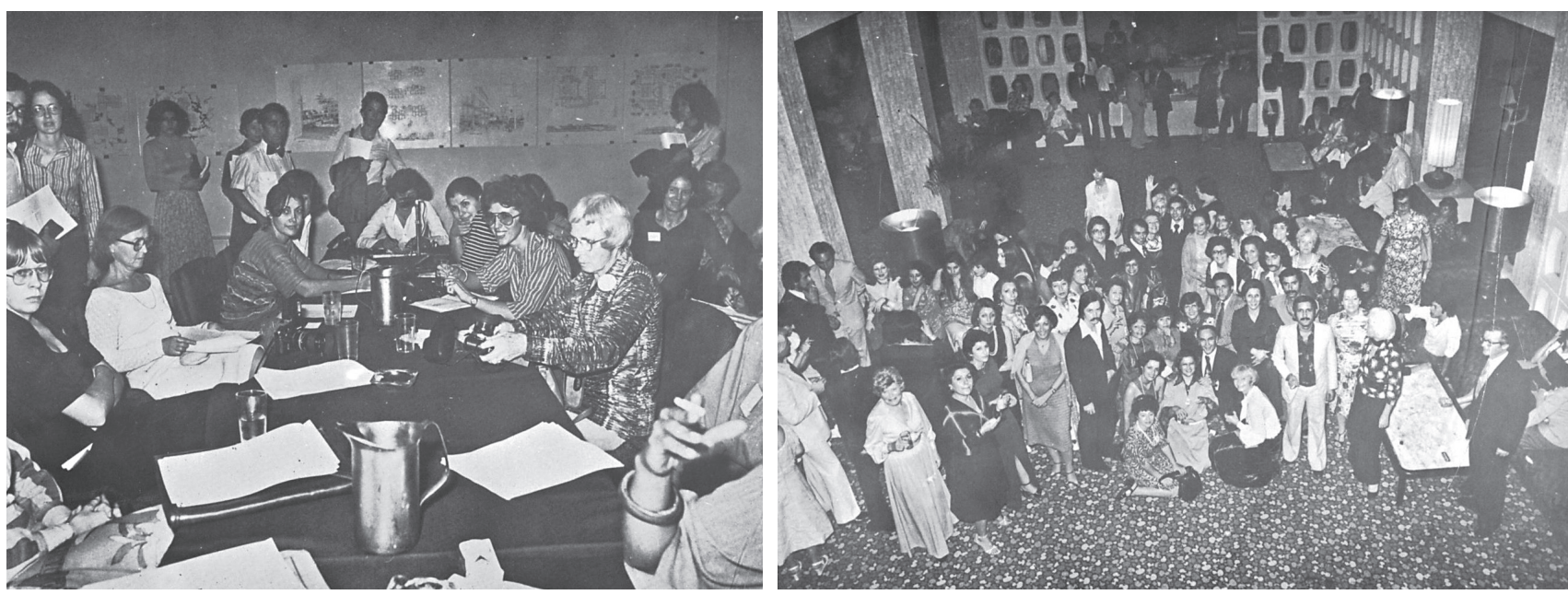
emphasized on the Pahlavis' contribution in reforming "the position of women in [the profession of] architecture" (Andref, 1977).

The theme Crisis of Identity in Architecture was tackled by the participants from two different perspectives; those who preferred to remain gender neutral and those who choose to make explicit their gender status in relation to the profession. Within this scope, the three subthemes provided a general framework to organize all differing aspects of various relations between gender and architectural practice (Figure 8).

In the following sessions, the sub-theme of the search for identity was explored under the chairmanship of Madame de la Tour with a lecture on The Identity Crisis: Its Nature and Expression by the Iranian philosopher and city planner Bakhtiar. The writer of The Sense of Unity: The Sufi Tradition in Persian Architecture, Bakhtiar asserted the word identity in reference to consciousness of self (Bakhtiar 1977, 21-7). The key concept of search for identity in Smithson's presentation, The Nature of Identity, is explored in reference to modern architecture. She argued that identity is contained within the idea of invention and that is the essence of modern movement in architecture (Smithson, 1977, 59-64). The lack of identity in Nigerian architecture was the main subject of the African participant, Sohande. Arguing that the high-rise dwelling apartments were a modified copy of modern architecture, she felt the key to the search was to hold onto one's cultural heritage (Sohande, 1977, 97). Similarly, Bellizzia explored the crisis in identity in the case of Mexican architecture, expressing that the recognition of one's culture would lead to a sense of identity in architecture and that technological transformations locked in cultural references result in aggression and loss in the essence of identity (Bellizzia, 1977, 155-7). Identity Thresholds of Individual and Community in the Forming of Cities was presented by the Chinese architect, Tyng. Tyng's lecture brought a different perspective into the concept; she remarked that in search for identity the thresholds of consciousness hidden in geometry need to be emphasized to reaffirm the individual and humanize the density of the city life (Tyng, 1977, 130).

The second sub-theme, the crisis in architecture was initiated by Drew's presentation. She described the role of architecture as to respond to requirements. Any attempt without considering social, cultural, physical, technical and economic conditions, in Drew's lecture, was introduced as a crisis in identity (Drew, 1977, 31-5). The crisis in Ehsan's presentation was examined through defining the interrelation between the two phenomena: knowledge and change. Ehsan indicated that in the urban environment, individual knowledge needs to incorporate social and physical transition in order to harmonize with the dynamic entity of the city. The disparity between the accumulated technology in the urban framework and the individual adaptiveness brings a gap which reinforces social conservatism and results in built-in obsolescence in urban areas (Ehsan, 1977, 67-73). Bofill (1977) in Design as a Response to People's Dreams indicated identity in culture and highlighted that architecture should propose alternatives to deal particularly with the problems and different traits of urban spaces. Bofill (1977, 77-9) rejected the possibility of having an international style in architecture, which she said resulted in a lack of identity and crisis. The crisis in identity in Motamed's presentation was covered through a different perspective. The breakdown of rural economics and mass migration during the period of rapid industrialization, said Motamed, brings acute problems in the field of low cost housing 
(Motamed, 1977, 83). Questioning the crisis in identity in the case of housing production, Nakahara introduced the prerequisites for achieving successful architectural production in the case of cooperative works in Japan (Nakahara, 1977, 91). The crisis and search for cultural identity in Fleming's lecture was examined in the case of Finland. Fleming stated that the rapid industrialization in the post-war period resulted in a "cultural shock" in Helsinki (Fleming, 1977, 101). Suher's lecture was an experiment dealing with the problems arising from the rapid technological progress in developing countries as in Turkey's case. The disappearance of environmental values and the emergence of squatters were accepted as the natural response of an unparalleled development between urbanization and industrialization in rural settlements which results in the crisis of identity in architecture (Suher, 1977, 147-51). Similarly, as the product of rapid urbanization and rural immigration, the development of architecture for society in meeting the problem of shelter was another perspective in identifying the crisis in the case of Iranian architecture by Marefat. Questioning the problems of mass-production, as an imitated version of Western modern architecture, Marefat introduced the architecture for society as an 'irrelevant architecture' with no root and identity (Marefat, 1977, 197-9). In a similar manner, A Crisis in Conception concentrated on the problem of shelter within the scope of urban and rural planning in post-colonial India. Rai's lecture described the crisis in identity through focusing on unplanned city growth in the capital (Rai, 1977, 217-20). Referring to Heidegger's assertion on the plight of dwelling, Faghih introduced the crisis as a product of the reduction of all references in the architectural production to more sociological concepts and patterns (Faghih, 1977, 181).

Initiating the third sub-theme of the Role of Women in the Crisis and Search for Identity, Brown remarked on the various forms of discrimination she encountered as a partner in the profession in Sexism and the Star System in Architecture. As the wife and the partner of well-known architect Robert Venturi, Brown attributed such experiences to the "star system" in architecture (Brown, 1977, 39). Published in 1989 for the first time, the article, however, was first presented and reproduced in the congress' report of proceedings thirteen years earlier in 1976. The Crisis of Identity in architecture was explored in some text through the main theme of gender and women's emancipation. Ruiter's approach provided a basis for a feminist philosophy of building and construction through which she analyzed the consequences of urbanization and the role of women architects in regard to improving the built environment (Ruiter, 1977, 167-77). In The Cultural Identity of Women Architects in U.S.A. Young (1977) highlighted that discrimination against women is the product of social tradition in America. She informed the members about the American Institute of Architects' resolution and the Affirmative Action Plan in ameliorating the status of women in architecture (Young, 1977, 187-9). Similarly, Tanzmann described the activities provided by the professional organization of women architects in affirming the position of women in the architectural profession in the Los Angeles (Tanzmann, 1977, 191-4). Whitley located the crisis in the search for identity within the process in planning with community participation with respect to different perspectives of design professions. Racial identity was studied in the case of black communities in the United States (Whitley, 1977, 203-16).

The concluding lectures were presented by Berkeley and Chahrouzi to inform the conference of architectural education in the world, especially 
in the case of the U.S.A and Iran. Berkeley's lecture concentrated on the identity crisis of individual and in particular among women architects in America via focusing on the activities of the American Institute of Architects in working to eliminate gender discrimination in architectural practice (Berkeley, 1977, 247-54). Chahrouzi's lecture, however, was a historical analysis of general trends in the architectural profession in the world and in Iran: while criticizing the course of proceedings and exploring the role of the architect in serving and reformulating the system (Chahrouzi, 1977, 257-60). In the final day of the congress, an architectural exhibition devoted to the works of some women architects was presented (Faridi, 1977, 9).

\section{A GENDER BIAS? SEARCHING FOR A PARALLEL HISTORY}

As mentioned, in 1975, the idea of an international convention on women architects emerged from Shahbanu Farah. Tehran Journal had promulgated the congress as the "big event" and in fact, it was in essence since it had been proselytized for the status quo. It had been for more than three decades that women had been accepted into the schools of architecture. The profession had been feminized in Pahlavi Iran with changing status of women and their participation in the field of architecture, yet gender representation in architectural practice had been virtually non-existent in the pages of the architectural press.

It had been rare to find a mention of women's work as architects but during the events of the congress their involvements indeed became evident in the pages of Arts and Architecture. To the Iranian attendees, however, the aim of the congress was not to encounter overt discrimination against women architects neither was it a search for an equal recognition for women's work by identifying their architectural practice during the second Pahlavi period. The Tehran Journal propagated the event in an article entitled as "Not a women's lib affair" through which Faridi, the leading organizer of the congress said, "Quite frankly, we just don't think of ourselves as women in our professional activities [in Iran] there is not any problem there." She continued "we will be exploring [the theme] in the same way men architects all over the world are discussing it today" (Shaghaghi, 1976b). Similarly, Azemun in an article in the Journal of Art and Architecture remarked that "this congress would prove the lack of sexual discrimination" (Women Architects, 1976) in Iran. Ehsan, a member of the organizing committee of the congress, several years later in an article in The Sophia Echo evaluated the condition of women architects in Iran, stating that "Iranian women were far more advanced than those in the United State in certain areas" (Figure 9). She declared that, "when I finished university in Iran ... I was one of nineteen girls in my class [however] when I went to the US in 1969 for my graduate studies, I was the first girl in the school of architecture for my program" she added "[our society] lacked discrimination towards women [and] that goes back to the history of Persia ... when the woman was a leader" (Ehsan, 2002). In the same manner, Kardan, the representative of Iran in the event stated that considering the issue of sexual discrimination in the developed countries, it was a privilege to be a woman architect in Iran, adding "a Swiss participant of the congress who won an architectural competition in her country was banned from construct her project just because she was a woman" (Women Architects, 1976). Similarly, many participants from Iran observed that the congress was not an experience in women's assertion of their rights since, 
Figure 9. Noushin Ehsan received the first prize for hotel design from the Queen of Iran (Noushin Ehsan's Private Archive, 2010)

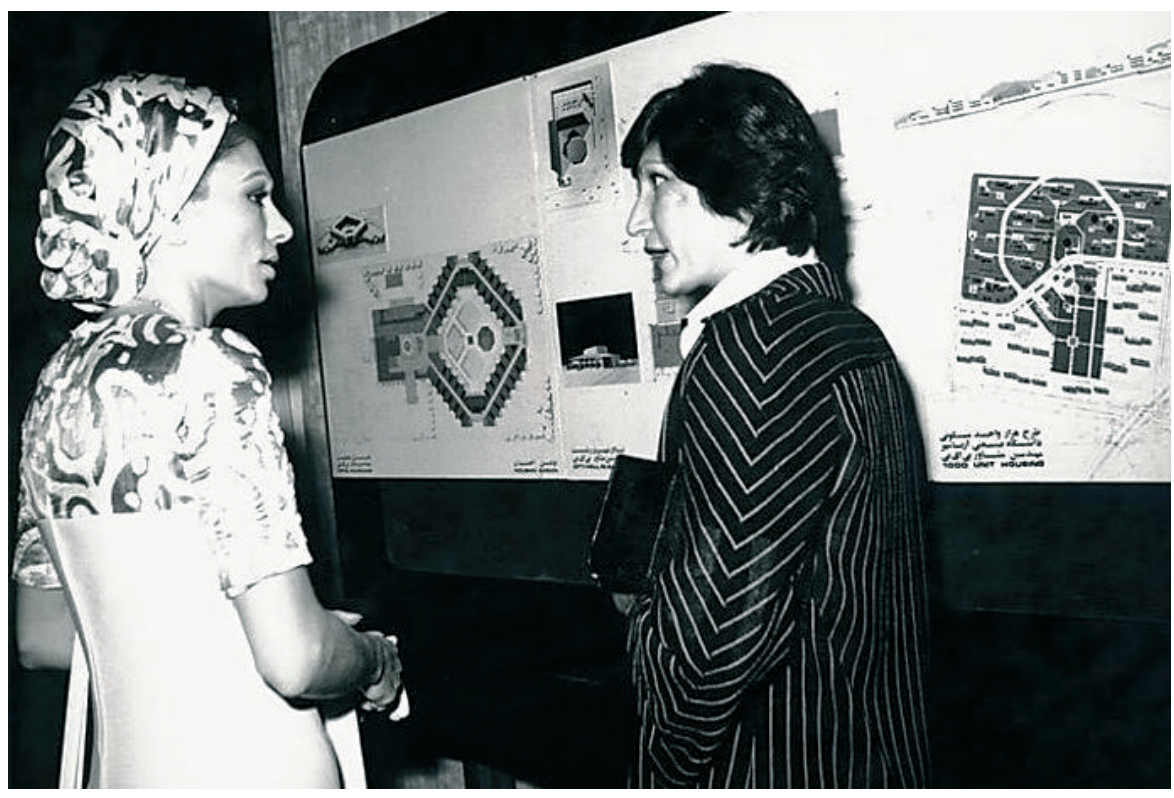

as highlighted by Andref, "science has nothing to do with the distinctions between men or women" (Shaghaghi, 1976a). Ehsan pointed out that "women architects apparently feel it is something of an advantage to be a female in their field here in Iran" further underlining "if anything, people here are so happy to see women achieving things in [the architectural] profession in Iran" (Shaghaghi, 1976b).

Yet, the reflections of the gathering in the print media are diversified. Not all the members of the international delegation agreed on the worthlessness of the organization around female architects. In another article in the Tehran Journal, the event was described as "Architects Get a Break from the Kitchen Sink" in which Mahnaz Afkhami, the former Secretary General of the Women's Organization of Iran and the Minister of State for Women's Affairs, expressed optimism on remarks preceding the inauguration of the event: "[I] would have preferred the theme of the conference to relate more specifically to the problems encountered by female architects, rather than encompassing the broad topic of the 'Identity Crisis in Architecture'"'. She said that "women could be more effective architects in many areas than their male counterparts, being generally more familiar with the problems of the home" (Shaghaghi, 1976a). In Afkhami's description, women architects are constrained by the ideological framework which delineates the patriarchal boundaries of their status in the architectural profession. Women are subcategorized to solving the problems of domesticity.

Whether the event functioned as a showcase for gender liberation or feminine representation in Pahlavi Iran through the inclusion of a group of "distinguished" female architects is still a question mark since Tehran Journal noted that all the members associated with the congress were "some of the world's very top women architects" (Shaghaghi, 1976b). One question hitherto unexplored is if these very elite and articulate[d] group could compass a mass, and provide an appropriate image of women architects in Pahlavi Iran. All the members associated with the organization had high-range qualification that "makes them superior rather than inferior to their male colleagues" (Shaghaghi, 1976b) since they were the representatives of Pahlavi Iran to the Western world, and exemplars of 
how women architects were trained in modern Iran. The congress served to acquaint nineteen participants from Iran among them Andref, the first Iranian woman to gain entrance to the department of architecture was a Tehran University graduate with an equivalent Ph.D. degree from Beaux Art in 1956. Faridi was a graduate who received her master degree in Urban and Regional Planning in the University of Strathclyde in 1970. Receiving her Bachelor degree from Tehran University, Ehsan had a double master degree of Urban Design and Architecture from U.C.L.A and a Ph.D. degree from MIT. Faghih was a Yale University graduate who gained her Ph.D. in Venice and Motamed received her postgraduate degree from Bartlett School of Architecture. "There are a lot of other women architects with high qualifications here [...] there was no reason to praise them" alleged Faridi to an interview with Tehran Journal, adding "go and talk to the others, you will find it very stimulating" (Shaghaghi, 1976b).

Foreign participants, however, complained about their public status and recounted how they had suffered in their profession. Searching for the participants, Ehsan dictated, "funny enough we had the most difficult time to find women architects in America and Denise Scott Brown was the one... and yet in the places like India, we have much more easy time to find upstanding women architects" (Ehsan, 2010). Similarly, the American participant, E. Berkeley raised the crisis women architects were facing in the architectural profession in U.S.A, stating "it has taken women a long time to become accepted in a profession that is still thought of as 'a man's profession' [in America] and the process is not yet complete". She referred to an article entitled 'A Thousand Women in Architecture' and stated that, although it had been for more than a hundred year that the first women architects enrolled in the profession (Berkeley, 1977), the proportion of women architects in America was under four percent. Many of the prestigious schools of architecture such as Harvard, said Berkeley, accepted women after the War because of the decline in the number of male architects during 1942. She added that: "there was a considerable battle at Harvard, at the time, about whether to accept women simply as students or to accept them as candidates for degrees and whether to continue the policy after the war" (Berkeley, 1977). Expressing the same sentiments were the leading members of the International delegation such as the British architect J. Drew, the city planner J. Whitley from the United States and A. Bofill of Barcelona exposed many forms of discrimination experienced by women in architecture such as less salary, less responsibility, less recognition and more difficulty finding work. Many of the participants, accordingly, worked in a family concern as a partner in the firm (Shaghaghi, 1976c). On the contrary, M. Laurola from Finland reported the good situation women architects had in her country, saying "fully a third of the leading Finnish architects are female. They are active... and are quite powerful on the cultural scene" (Shaghaghi, 1976c). Similarly, the visiting architect, I. Rai indicated architecture as an active field for women in India (Shaghaghi, 1976c). In an article in the Journal of Art and Architecture, comparing the activities of women architects in Iran and the United States, Ehsan indicated that "it was in the U.S.A that I recognized that I am a woman for the first time and this would prevent my success in the field" (Women Architects, 1976) expressing "I found everywhere that I was going... I was the first woman architect in UCLA Master Program at Architecture... every offices I worked I was the first woman architect... then I taught at IPR in $1974 \ldots$ and I was the first woman architect at Harvard Graduate School of Design... and yet in Iran we [female architects] 
were progressed and I think we had more problems in Western World than Middle East" (Ehsan, 2010).

In an article in the Tehran Journal, J. Shaghaghi interpreted the difference in the status of women architects in Iran and abroad in these words: "since there is a relatively limited number of architects in Iran, there is less discrimination against women in favor of men. Whereas in the Western countries, young architects must study and serve apprenticeships for as long as ten years before establishing successful practices, Iranian architectural students are securing commissions as early as in their second year of studies" (Shaghaghi, 1976d).

The analysis of International Congress of Women Architects demonstrates the Pahlavis' contribution in uncovering evidence of women's roles in constructing modern Iran. Explicitly or implicitly, women architects had always fulfilled a marginalized position in the profession. Encountering obstacles created by gender prejudice in their profession, gender-bias representation had been marginally obscure; women were indeed omitted. The congress and accompanying report of the proceedings and publications, however, provided research and the only documentation regarding the work of the first generations of female architects in Iran.

In discussing the public status of women architects in Iran Ehsan said that in practice many women architects preferred to remain invisible in their gender status; they choose to operate solely as architect in their profession. She emphasized that, working as prominent professionals, female architects do not need raise issues of gender in relation to their activities and that is the basic reason for their absence from publicity (Ehsan, 2010).

While many of the Iranian attendees agreed that the congress was not a feminist gathering per se, the main theme was informed by a gendered perspective by diverse participants as the first all-women conference on architecture in Iran and more importantly as the fourth international assembly devoted to women practitioners in the world.

\section{CONCLUSION}

The last decade of the Pahlavi era marks a crucial turning point in the enforcement of comprehensive social, political and cultural reform programs aiming at the deep transformation in the Iranian modernity; while the state co-opted all the processes of high-culture, architectural discourses increased in scope to achieve their political undertone. Various events were accordingly supervised by the institution of monarchy, and in particular under the female royal patronage of Shahbanu Farah as the leading promoter of high-culture. Building a home, a library, a secretariat, exhibition halls, museums and art centers. She was also involved in organizing festivals, symposiums and conferences in various fields of arts and architecture. Each of these projects reveals the experience of a particular form of modernity which was predefined by the Pahlavis' very reformist ideologies. Organized in 1976, as one of her latest drive towards modernization, the idea for the International Congress of Female Architects was more than an attempt in acculturating the nation; the event can be seen as a showcase in fostering the state's gender-bias ideologies and women integration in constructing modern Iran and its architecture.

Neither was the desire of the authorities nor the intention of those who championed legal changes (Sanasarian, 1982.), feminism, was a tool in 
gender legalization that enhanced the image of the shah as a modern monarch of a modern state and a modern nation. Unlike their predecessors, the Pahlavis were conscious of and fully accepted women's argument that development was impossible without the full integration of women and a complete change in their status. Assuming social, political, cultural and educational integration, the Pahlavis' gender-base reforms vested Iranian women legal authority in consolidating their integration in all those fields there were always seemed to be absent including arts and architecture.

If modern woman were perceived as an instrument ideologically promoting the Pahlavis' posture and in the service of the state, the idea for all-women convention on architecture can be identified as a remarkably act in challenging the legitimacy of sexual absolutism on both the national and international orbits. The event can be seen as vital, albeit symbolically, in deconstructing the parameters of the patriarchal structure of Iranian modernity. Furthermore, the congress can be accepted as influential in rethinking an alternative, gender-based narration of Iranian architectural history. Questioning marginalization of female architects and their works also deeply affected the traditional history and historiographic canon which was based on exclusionary practices of Pahlavi women builders and covered exclusively male gendered subjects as active agents in constructing modern Iran and its architecture. The event was, accordingly, a subversion of the masculine myth of modernity by a feminine perspective.

\section{BIBLIOGRAPHY}

AFKHAMI, M. (1983) The Women's Organization of Iran: Evolutionary Politics and Revolutionary Change, Women and Revolution in Iran, ed. G. Nashat, Westview Press, Colorado, 5-35.

ANDREF, N. P. (1977) The Crisis of Identity in Architecture, The Hamdami Foundation, Tehran, 11.

ARDALAN, N. (1986) Architecture VIII. Pahlavi, after World War II, Encyclopaedia Iranica, 351-5.

BAKHTIAR, L. M. (1977) The Identity Crisis: Its Nature and Expression, The Crisis of Identity in Architecture, The Hamdami Foundation, Tehran, 21-7.

BLANCH, L. (1978) Farah, Shahbanu of Iran, Collins, London.

BELLIZZIA, N. G. (1977) Identity as Mode of Being, The Crisis of Identity in Architecture, The Hamdami Foundation, Tehran, 155-7.

BERKELEY, E. P. (1977) Identity Crisis in Architecture, The Crisis of Identity in Architecture, The Hamdami Foundation, Tehran, 247-54.

BOFILL, A. (1977) Design as a Response to People's Dreams, The Crisis of Identity in Architecture, The Hamdami Foundation, Tehran, 77-9.

BOLA, S. (1977) The Crisis od Identity on Architecture: Nigeria, West Africa, The Crisis of Identity in Architecture, The Hamdami Foundation, Tehran, 97.

BROWN, D. S. (1977) Sexism and the Star System in Architecture, The Crisis of Identity in Architecture, The Hamdami Foundation, Tehran, 39.

CHAHROUZI, Y. (1977) Architectural Education in Iran, The Crisis of Identity in Architecture, The Hamdami Foundation, Tehran, 257-60. 
DREW, J. B. (1977) The Crisis in Identity in Architecture, The Crisis of Identity in Architecture, The Hamdami Foundation, Tehran, 31-5.

EHSAN, N. (2010) Conversation with the Author, New York.

EHSAN, N. (2002) Serving and inspiring people, The Sophia Echo 6 (25).

FAGHIH, N. (1977) On Building as the Making of the World, The Crisis of Identity in Architecture, The Hamdami Foundation, Tehran, 181.

FARIDI, A. (1977) Report of the Congress by the Secretary General, The Crisis of Identity in Architecture, The Hamdami Foundation, Tehran, 9.

FLEMING, T. (1977) Cultural Shock in Fast Developing Communities, The Crisis of Identity in Architecture, The Hamdami Foundation, Tehran, 101-3.

KHAJOUY, G. R. (1946) The History of the Faculty of Fine Arts, Architect 3 (1).

MANSOURI, A. (2007) Iranian Architects Book, Nazar Publication, Tehran.

MAREFAT, M. (1977) Shelter, The Crisis of Identity in Architecture, The Hamdami Foundation, Tehran, 197-9.

MOTAMED, L. F. (1977) Low Coast Housing: A Cultural Reawaikening or an Endemic Disease?, The Crisis of Identity in Architecture, The Hamdami Foundation, Tehran, 83.

NAKAHARA, N. (1977) Production of Housing Tokyo and its Future in Japan, The Crisis of Identity in Architecture, The Hamdami Foundation, Tehran, 91.

PAHLAVI, F. (2004) An Enduring Love: My Life with the Shah, Miramax Books, Hyperion.

RAI, I. (1977) A Crisis in Conception, The Crisis of Identity in Architecture, The Hamdami Foundation, Tehran, 217-20.

RUITERS, N. C. (1977) An Approach to the Relation Between Women and Environment, The Crisis of Identity in Architecture, The Hamdami Foundation, Tehran, 167-77.

SANASSARIAN, E. (1982) The Women's Rights Movement in Iran, Praeger, New York.

SHAGHAGHI, J. L. (1976a) Architects Get A Break From The Kitchen Sink, Tehran Journal, 8.

SHAGHAGHI, J. L. (1976b) Not A Women's Lib Affair, Tehran Journal, 1.

SHAGHAGHI, J. L. (1976c) Petticoat Preview on Ramser Meet, Tehran Journal, 3.

SHAGHAGHI, J. L. (1976d) Women's Role in Architecture, Tehran Journal, 3.

SMITHSON, A. (1977) The Nature of Identity, The Crisis of Identity in Architecture, The Hamdami Foundation, Tehran, 59-64.

SUHER, H. (1977) Disappearance of Some Environmental Values in the Process of Urbanization, The Crisis of Identity in Architecture, The Hamdami Foundation, Tehran, 147-51. 
TABIBI, B. (2014) Propagating “Modernities": Art and Architectural Patronage of Shahbanu Farah Pahlavi, unpublished PhD Dissertation, The Graduate School of Social Sciences, METU, Ankara.

TANZMANN, V. (1977) Women Architects in the Los Angeles Area, The Crisis of Identity in Architecture, The Hamdami Foundation, Tehran, 191-4.

TYNG, A. G. (1977) Identity Thresholds of Individual and Community in the Forming of Cities, The Crisis of Identity in Architecture, The Hamdami Foundation, Tehran, 130.

U.I.F.A. (2008) [http://www.uifa.fr/home.htm] Access Date (12.12.2009).

WHITLEY, R. J. (1977) Planning and Designing with Community Participation: Experience with Black Communities in the United States, The Crisis of Identity in Architecture, The Hamdami Foundation, Tehran, 203-16.

WOMEN ARCHITECTS (1976) Journal of Art and Architecture, 35-36.

YOUNG, J. (1977) The Cultural Identity of Women Architects in U.S.A, The Crisis of Identity in Architecture, The Hamdami Foundation, Tehran, 187-9.

Alındı: 06.06.2020; Son Metin: 01.03.2021

Anahtar Sözcükler: Kadın mimarlar; Bani kadınlar; İran mimarisi; Pahlavi modernitesi; Şahbanu Farah Pahlavi

\section{PAHLAVİ MODERNLEŞMESINNDE YARATICI KADINLARIN GIZLII KALMIŞ PORTRELERİ: KADIN MIMARLAR KONGRESINIIN YENIDEN DEĞERLENDİRILMESI}

Pahlavi döneminde, hem yüksek kültürün hem de devlet feminizminin tezahüründe meydana gelen yaklaşım değişimi rastlantısal değildi. İkisi de aynı ideolojik gündemin ayrılmaz birer parçasıydı: modernitenin gündemi. Her ikisi de iki Pahlavi hükümdarı Reza Şah ve halefisi Muhammed Reza Şah'ın siyasi düşünce yapılarının somut birer parçasıydı. Her ikisi de emperyal gücü ellerinde bulundursalar da, ikisinin ortak özelliği, Şahbanu Farah Pahlavi ve onun çevresindeki modern İran kadın sanatçı ve mimarlarında saklıydı. Şahbanu'nun gücü, yalnızca İran tarihinde resmi olarak ilk taçlandırılan kraliçe olmasından degil, aynı zamanda devletin tüm işlerinde yasal otorite olarak tanınan nihai bir kadın modeli rolünü üstlenmesinden kaynaklanıyordu. Mimarlık eğitimi alan ve tahta geçme hakkını kazanan şahbanu, İran Monarşisinin son on yılında devletin kültürel gündemini oluşturacak konumdaydı. Çeşitli ulusal ve uluslararası etkinliklere hamilik eden şahbanu'nun salt kadın mimarlara yönelik düzenlediği kongre, hükümetin toplumsal cinsiyet eşitliğini destekleyen, modern İran ve mimarisini inşa etmede kadınların temsilini meşrulaştıran bir girişim olarak görülebilir. Kısacası, devrim öncesi dönemde, yüksekkültür ve feminizm, ütopyacı bir modernitenin nihai belirleyici unsurları arasında tanımlanırken, kadın sanatçı ve mimarlar da devletin ideolojik işeleyişini tasarlayan ve uygulayan özneler olarak onlara önceden tanımlanmış rolleri üstlenmeye başladılar; bu politika ve onun mimari ifadesi arasındaki ilişkiyi kaçınılmaz kıldı. 


\section{UNHIDING THE HIDDEN PORTRAIT OF PAHLAVI WOMEN BUILDERS IN SKETCHING THE IRANIAN MODERNITY: A REASSESSMENT OF THE CONGRESS OF WOMEN ARCHITECTS}

Throughout the Pahlavi era, the paradigm shift that took place in both the manifestation of high-culture and of state-feminism was not coincidental. They were both integral to the same ideological agenda: that of modernity itself. Both provided a concrete form of emerging political ideas under the two Pahlavi monarchs, Reza Shah and his successor Mohammad Reza Shah. And, both were instruments in promoting the state posture and acted in the service of the government. While both enjoyed imperial patronage, the features they jointly characterized were embodied in the shahbanu of Iran, Farah Pahlavi and her entourage, a group of well-educated women, in artistic and architectural arena. The shahbanu's power was exemplified by her part in a highly legal event of coronation ceremony at which she was not only announced as the first officially crowned queen in the Iranian history, but also as an ultimate model of emancipated woman vested with legal authority in all affairs of the state. Studied architecture, as a queen regent, the shahbanu was in the position to implement the state's cultural agenda during the last decade of the Iranian Monarchy. Patronizing various national and international architectural events, the idea for a congress devoted to female architects is accepted as a remarkable act, affirming gender equality and women representation in constructing modern Iran and its architecture. A decade preceding the Islamic Revolution, accordingly, can be defined by the epitomization of high-culture and feminism as the ultimate signifiers of a utopian modernity, wherein women builders came to play their substantial role, albeit superficially, through the fully crystalized apparatus of culture; this made the relationship between politics and its architectural expression an imperative one.

BAHARAK TABIBI; B.Arch, M.Sc., PhD.

Received her B.Arch from Uludağ University, Faculty of Engineering and Architecture (19962000). Earned her M.Sc. in architecture and PhD degree in architectural history from Middle East Technical University (2014). Major research interests include gender and architecture, and history and historiography of Modern Architecture in the Middle East.

baharak.tabibi@okan.edu.tr 